\title{
The Protein Synthesis of Human Full Term Placenta Cell in Monolayer Gulture System
}

\author{
Hideaki Kono, Young Chin Lin, Mamoru Yamaguchi, ${ }^{*}$ \\ Atsushi Sanbuissho, ${ }^{*}$ Frederick P. Zuspan, $\dagger$ Nobuyuki \\ Furuhashi $\ddagger$ and Akira Yajima \\ Department of Veterinary Physiology and Pharmacology, \\ *Department of Veterinary Anatomy, †Department of \\ Obstetrics and Gynecology, The Ohio State University, \\ Columbus, OH, USA, \$Department of Obstetrics and \\ Gynecology, Ota General Hospital, Koriyama 963, and \\ §Department of Obstetrics and Gynecology, Tohoku \\ University School of Medicine, Sendai 980
}

Kono, H., Lin, Y.C., Yamaguchi, M., Sanbuissho, A., Zuspan, F.P., Furuhashi, N. and Yajima, A. The Protein Synthesis of Human Full Term Placenta Cell in Monolayer Culture System. Tohoku J. Exp. Med., 1990, 161 (1), 43-47 — Protein synthesis of human placenta from cesarean section was analyzed by SDS gel electrophoresis using full term cell culture system. The qualitative pattern of cytoskeletal proteins before and after culture was also examined. After trypsinization, cytotrophoblasts were cultured for 20 days in the humidified incubator of $5 \% \mathrm{CO}_{2}$ in $95 \%$ air. The confluency was obtained in 10 days after inoculation. The pattern of SDS-PAGE showed several protein bands including actin $(43,000 \mathrm{Da})$ and desmin $(55,000 \mathrm{Da})$ as major constituents of 12 and 20 day cultures. The significant differences between band appearances in samples before and after culturing were noted. The present results indicated that myosin may not be synthesized in high content, differing from previous observations. Cytoskeletal protein production seemed to be markedly enhanced in the cultured system - protein synthesis ; placenta ; cell culture; SDS-PAGE ; actin

Trophoblast cell is the first tissue which grows after fertilization. Ultrastructural study of the trophoblast shows that there is considerable difference in morphology between the syncytiotrophoblast and the cytotrophoblast (Dearden and Ockleford 1983). In addition, trophoblast cell after fertilization is associated with the development of cytoskeletal proteins, especially actin and myosin (Huszar and Bailey 1979b; Sobel et al. 1980). Recently many human placental plasma membrane proteins have been examined (Whyte 1983; Emerson et al. 1985 ; Webb et al. 1985). However, little is known about the proteins of the full term placenta (Kubo et al. 1984 ; Daniels-McQueen et al. 1987). In order to

Received Februaly 13, 1990 ; revision accepted for publication April 15, 1990. 
elucidate protein fractions synthesized in the trophoblast, we studied the changes in the pattern of cytoskeletal protein synthesis by means of one dimentional gradient SDS-PAGE using three trophoblast cell groups: Trophoblast before culture, trophoblasts cultured for 12 days, and trophoblasts cultured for 20 days.

\section{Materials and Methods}

\section{Cell culture}

Human full term placentas $(n=10)$ were used for our study. All the placentas were delivered after elective cesarean section at the Ohio State University Hospital. Placenta was immersed in $4^{\circ} \mathrm{C}$ saline, and washed to remove red blood cells. Amniotic and decidua membrane of the placenta were resected. Chorionic villi were removed from the placenta and placed into petri dish with Dulbecco's modified Eagle medium supplemented with aminobenzil-penicillin $(100 \mu \mathrm{g} / \mathrm{ml})$ and streptomycin $(100 \mu \mathrm{g} / \mathrm{ml})$ (DMEM, $\mathrm{pH} 7.4)$. About $10 \mathrm{~g}$ of chorionic villi per one placenta was dissected, and cut into the size of $2-3 \mathrm{~mm}$ in diameter by scissors. After three changes of DMEM, $10 \mathrm{~g}$ of dissected chorionic villi was placed in $100 \mathrm{ml}$ volume bottle with $90 \mathrm{ml}$ of $0.25 \%$ trypsin diluted by DMEM. The tissue was stirred by magnetic stirring bar ( $2 \mathrm{~cm}$ in diameter) in low speed for $30 \mathrm{~min}$ in water bath at $37^{\circ} \mathrm{C}$. The supernate was pooled in the beaker with $50 \mathrm{ml}$ of DMEM containing $10 \%$ fetal calf serum on ice. The residue in the bottle was retrypsinized with $90 \mathrm{ml}$ of $0.25 \%$ trypsin diluted by DMEM. The trypsin treatments were repeated for periods of 60,90 and $120 \mathrm{~min}$. After the final trypsinization we got about $300 \mathrm{ml}$ cell suspension. The suspension was filtered through $100 \mu \mathrm{m}$-mesh screen sieve to remove all fragments of tissue. Trophoblasts in the filtrate were pelleted by centrifugation at $300 \times g$ for $5 \mathrm{~min}$, and resuspended in $10 \mathrm{ml}$ of DMEM supplemented $10 \%$ fetal calf serum. The cell number was counted by a hemocytometer. The cell suspension was pelleted again by centrifugation at $300 \times g$ for 5 min. After decantation, $10 \mathrm{ml}$ of DMEM with $10 \%$ fetal calf serum was added to the pellet. This gave a cell yield of $12 \times 10^{6}$ cells $/ 10 \mathrm{~g}$ of wet tissue. $90 \%$ of cell viability was detected by trypan blue exclusion study. Five $\mathrm{ml}$ of $3 \times 10^{5} \mathrm{cells} / \mathrm{ml}$ was plated in $25 \mathrm{~cm}^{2}$ tissue culture flasks (Falcon Plastics, Oxnard, CA, USA), and incubated in a humidified atmosphere of $5 \% \mathrm{CO}_{2}$ in $95 \%$ air. The caps of flasks were screwed loose. Every $48 \mathrm{hr}$ the culture medium was removed, and replaced by fresh medium. The cell suspension was divided into 3 groups. One group had 5 flasks, each containing five $\mathrm{ml}$ of $1 \times 10^{5}$ cells $/ \mathrm{ml}$. Condition of the cultures were examined at $24 \mathrm{hr}$ intervals using an inverted phase-contrast microscope (TMD-2; Nikon, Tokyo). Confluence of culture was observed approximately 10 days after inoculation. Group 1 acted as the control with no culturing of cells. Group 2 was cultured 12 days and group 3, 20 days. All of the cultured cells were collected by rubber-policeman and suspended in $5 \mathrm{ml} 0.01 \mathrm{M}$ Tris-HCl buffer $(\mathrm{pH}$ 8.0) supplemented $0.25 \mathrm{M}$ sucrose, and were centrifuged at $300 \times g$ for $5 \mathrm{~min}$. After decantation $3 \mathrm{ml}$ of Tris-buffer was added to the pellet. The pellet was re-centrifuged. After decantation the cell pellets were solubilized with $0.5 \mathrm{ml}$ of $0.01 \mathrm{M}$ Tris-HCl buffer containing $0.25 \mathrm{M}$ sucrose ( $\mathrm{pH} 8.0)$. The suspension was mixed by vortex, and sonicated for $15 \mathrm{sec} 3$ times for cell dispersion. Final volume of $0.5 \mathrm{ml}$ was obtained. The protein concentration was determined by the Bradford method using Biorad protein assay kits.

\section{One dimentional gradient SDS-PAGE}

A portion of sample suspension was treated with equal volume of concentrated lysis buffer according to Laemmli's method (Laemmli 1970). The sample was sonicated for 2 min and boiled in the water basin for 2 min. After cooling, samples were transferred into the celophan tube, and dialyzed for $24 \mathrm{hr}$ with magnetic stirring bar in the buffer containing $1.515 \mathrm{~g}$ Tris, $5 \mathrm{~g}$ SDS, $30 \%$ glycerol $100 \mathrm{ml}, 2 \% 2$-mercaptoethanol $12.5 \mathrm{ml}$, and 5 drops of Bromphenol with $387.5 \mathrm{ml}$ deionized distilled water. The dialyzed samples were then 
condensed by using filtration condenser. The sample was then applied onto $7.5-20 \%$ gradient gel and electrophoresis was carried out at constant current of $1 \mathrm{mV}$ for $16 \mathrm{hr}$. Rabbit skeletal myofibril was used as standard protein in the electrophoresis process.

\section{RESUlts}

SDS-PAGE pattern is shown in Fig. 1. Rmf is rabbit psoas myofibril. Column $a$ is full term trophoblast, $b$ and $c$ are 12 and 20 day cell culture patterns, respectively. The band corresponding to desmin is distinctly visible in columns $b$ and $c$, but not $a$. Actin is more prominant in columns $b$ and $c$ but is only slightly visible in column $a$. The results show that actin, desmin, tropomyosin, and an unidentified protein band (m.w. : 46,000) between desmin and actin represent major changes of cytoskeletal protein from the original cells (before culture) to the 12 and 20 day cell cultures. Myosin heavy chain and $\alpha$-actinin

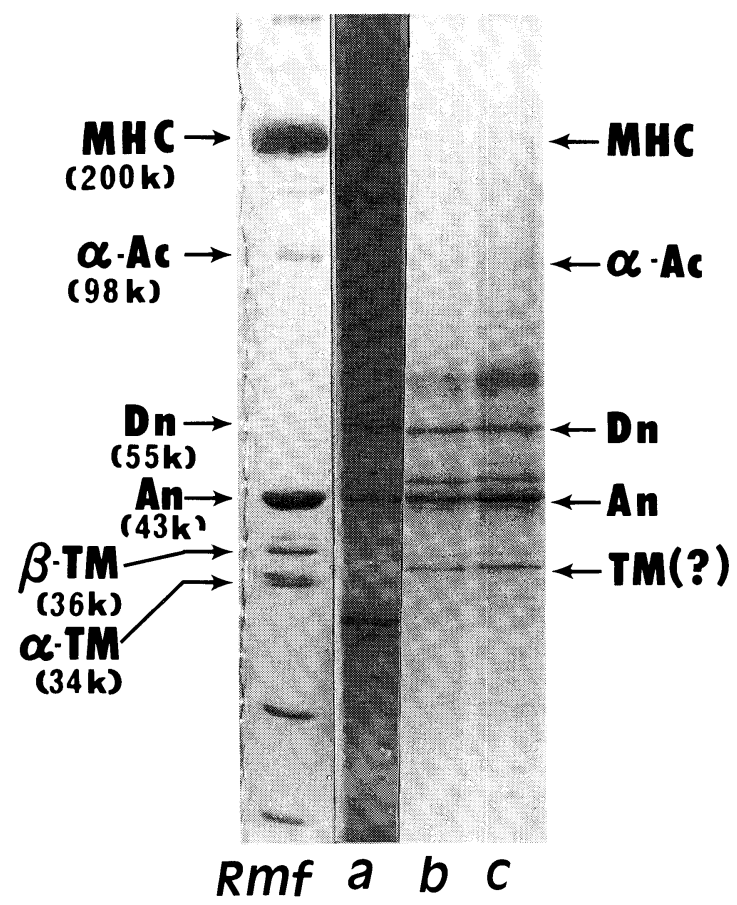

Fig. 1. SDS-PAGE pattern of trophoblasts.

Actin is more prominant in columns $b$ and $c$ than column $a$. Actin, desmin, tropomyosin, and an unidentified protein band (m.w. : 46,000) shows major changes of cytoskeletal protein from the original cells (before culture) to the 12 and 20 day cell culture. The qualitative pattern of protein synthesis might remain stable from 12 days after inoculation onward till 20 days in culture. Rmf, rabbit psoas myofibril ; Column $a$, full term trophoblasts before culture ; Column $b, 12$ day cell culture pattern ; Column $c, 20$ day cell culture pattern ; MHC, myosin (heavy chain); $\alpha$-Ac, $\alpha$ actinin; Dn, desmin; An, actin; $\beta$-TM, $\beta$ tropomyosin; $\alpha$-TM ; $\alpha$ tropomyosin; TM, tropomyosin. 
bands are slightly visible after 12 and 20 days. The diffuse protein band above desmin presumably represents the media protein albumin.

\section{Discussion}

We performed SDS gel electrophoresis on human full term placenta. The gel pattern showed that actin band can be recognized clearly even though other bands were extremely difficult to identify. The presence of actin, plasminogen, and transferrin has been reported in full term placenta by immunofluorescent method (Faulk and Johnson 1977). It was also indicated that in vitro trophoblast growth may be correlated with the formation of actin fibers (Faulk and Johnson 1977). Microfilament which consists of syncytioskeletal layer was identified as being composed of actin and tubulin polymer (Dearden and Ockleford 1983). Huszar suggested that myosin in placenta plays an important role during pregnancy (Huszar and Bailey 1979a). And in fact this was proven in mouse placenta during proliferation of trophoblast (Sobel et al. 1980). However, the present culturing data showed that actin-myosin interaction in human trophoblast might not occur in culture system. The present results proved that cytoskeletal proteins such as actin and desmin but not myosin are major synthesized proteins suggesting that the proliferation process may be similar to that of smooth muscle cells which often slows the synthesis of myosin in comparison to other cytoskeletal proteins. In addition, after the confluency of cultured cells no difference was found in the qualitative pattern of cytoskeletal proteins between trophoblasts cultured for 12 days and for 20 days. According to the mouse embryo culture study, it was indicated that major qualitative changes in the pattern of protein synthesis occur prior to four-to eight-cell stage, and that the qualitative pattern of protein synthesis remains unchanged from early day 3 onward (Blerkom and Brockway 1975). Our data showed that from 12 days after inoculation onward in culture the qualitative pattern of protein synthesis might remain stable till 20 days.

\section{References}

1) Blerkom, J.V. \& Brockway, G.O. (1975) Qualitative patterns of protein synthesis in the preimplantation mouse embryo. 1. Normal pregnancy. Dev Biol., 44, 148-157

2) Daniels-McQueen, S., Krichevsky, A. \& Boime, I. (1987) Isolation and characterization of human cytotrophoblast cells. In: Trophoblast Research 2, edited by R.K. Miller \& H.A. Thiede, Plenum Medical, New York - London, pp. 423-445.

3) Dearden, L. \& Ockleford, C.D. (1983) Structure of human trophoblast: Correlation with function. In: Biology of Trophoblast, edited by Y.W. Loke \& A. Whyte, Elsevier, Amsterdam - New York, Oxford, pp. 69-110.

4) Emerson, D.L., Werner, P.A, Cheng, M.H. \& Galbraith, R.M. (1985) Presence of $\mathrm{Gc}$ (vitamine D-binding protein) and interactions with actin in human placental tissue. Am. J. Reprod. Immunol. Microbiol., 7, 15-21.

5) Faulk, W.P. \& Johnson, P.M. (1977) Immunological studies of human placentae: Identification and distribution of proteins in mature chorionic villi. Clin. Exp. Immunol., 27, 365-375.

6) Huszar, G. \& Bailey, P. (1979a) Isolation and characterization of myosin in the 
human term placenta. Am. J. Obstet. Gynecol., 135, 707-712.

7) Huszar, G. \& Bailey, P. (1979b) Relationship between actin-myosin interaction and myosin light chain phosphorylation in human placental smooth muscle. $A m$. J. Obstet. Gynecol., 135, 718-725.

8) Kubo, H., Rin, K. \& Katayama, S. (1984) Deoxyribonucleic acid and protein synthesis in delayed mouse blastocysts in vitro. Acta Obstet. Gynaecol. Jpn., 36, 1187-1196.

9) Laemmli, U.K. (1970) Cleavage of structural proteins during the assembly of the head of bacteriophage T4. Nature, 227, 680-685.

10) Sobel, J.S., Cooke, R. \& Pedersen, R.A. (1980) Distribution of actin and myosin in mouse trophoblast: Correlation with changes in invasiveness during development in vitro. Dev. Biol., 78, 365-379.

11) Webb, P.D., Evans, P.W., Molloy, C.M. \& Johnson, P.M. (1985) Biochemical studies of human placental microvillous plasma membrane proteins. Am. J. Reprod. Immunol. Microbiol., 8, 113-119.

12) Whyte, A. (1983) Biochemistry of the human syncytiotrophoblast plasma membrane. In: Biology of Trophoblast, edited by Y.W. Loke \& A. Whyte Elsevier/ North Holland Biomedical Press, Amsterdam - New York - Oxford, pp. 513-533. 